\title{
The effects of mother education and intervening mechanisms on rural-urban child stunting: evidence from Pakistan
}

\section{Efeitos da escolaridade das mães e dos mecanismos intervenientes no déficit de crescimento de crianças de áreas rurais e urbanas: evidências do Paquistão}

\author{
Muhammad Umar Farooq (iD, Muhammad Zahid Rafique², Muhammad Abdul Rehman Shah ${ }^{3}$ \\ ' Government College University Faisalabad, Faisalabad, Punjab, Pakistan \\ 2 Shandong University, Jinan, Shandong, China \\ ${ }^{3}$ University of Engineering and Technology, Taxila, Punjab, Pakistan
}

\begin{abstract}
OBJECTIVES: Estimate the impact of mother schooling on rural-urban child chronic malnutrition from Pakistan. MATERIALS AND METHODS: The data on all education based pathways, such as socio-demographic and behavioral, were taken from Pakistan Demographic and Health Survey 2012-13 dataset. The data on all infants aged 0-59 months, whose height and weight were measured at the survey time, were selected for empirical analysis. Analyses with binary logistic regression model were used to determine the effect of mother formal schooling on rural-urban infant stunting after controlling for other factors deeply linked to her schooling. RESULTS: Empirical results showed that urban mothers having primary and secondary/ higher education have less likelihood of stunting for their infants than rural mothers relative to illiterate mothers, implying that illiterate mothers have more stunted kids. Male household head and poor economic rank have more likelihood of stunting in both locations, relative to female household head and rich households. Among explanatory variables, maternal schooling, health seeking attitude, socioeconomic rank, empowerment, and child weight are highly significant predictors of stunting in rural-urban Pakistan. Despite of earlier significant outcomes, targeted interventions are important aiming at mothers having no education. CONCLUSION: Female education, along with various other pathways (her socioeconomic, empowerment and heal seeking thought), has reduced chronic malnutrition and has been a guarantee of better living standard, still targeted interventions are important aiming at mothers having no education by specifying a big share of federal and regional budget on female education.
\end{abstract}

Keywords: Stunting; Empowerment; Binary Logistic Regression; Pakistan.

\section{RESUMO}

OBJETIVOS: Estimar o impacto da escolaridade das mães na desnutrição crônica de crianças de áreas rurais e urbanas do Paquistão. MATERIAIS E MÉTODOS: Dados relacionados à educação materna, como sociodemográficos e comportamentais, foram extraídos da Pesquisa Demográfica e de Saúde do Paquistão 2012-13. Dados sobre crianças de 0 a 59 meses de idade, cuja altura e peso foram medidos durante a pesquisa, foram selecionados para análise empírica. Análises com o modelo de regressão logística binária foram usadas para determinar o efeito da escolarização da mãe sobre o déficit de crescimento de crianças, após o controle de outros fatores ligados à sua escolaridade. RESULTADOS: Os resultados empíricos mostraram que as mães urbanas com ensino fundamental e médio/superior têm menor probabilidade de terem filhos com déficit de crescimento do que as mães rurais em relação às mães analfabetas; as mães analfabetas têm maior probabilidade de terem filhos com déficit de crescimento. Homens chefes de família e baixa renda familiar têm maior relação com o déficit de crescimento em ambos os locais. Entre as variáveis explicativas, escolaridade materna, atitude em busca da saúde, nível socioeconômico, empoderamento e peso da criança são preditores significativos de déficit de crescimento em áreas urbanas e rurais do Paquistão. CONCLUSÃO: A educação feminina, juntamente com outras variáveis (nível socioeconômico, empoderamento e busca por atendimento de saúde), tem reduzido a desnutrição crônica e sido uma garantia de um melhor padrão de vida; ainda assim, intervenções direcionadas são importantes para mães com baixo nível educacional, demandando investimentos na educação feminina.

Palavras-chave: Transtornos de Crescimento; Empoderamento; Regressão Logística Binária; Paquistão.

\author{
Correspondence / Correspondência: \\ Muhammad Umar Farooq \\ Government College University Faisalabad, Lecturer Department of Economic, Pakistan \\ E-mail: umarfarooggcuf@yahoo.com \\ Phone \#: +923346529615
}




\section{INTRODUCTION}

Growth and development of children is badly affected by malnutrition not only in short run but also in long run ${ }^{1,2,3}$. Malnourished children are physically, emotionally, and intellectually less productive and more susceptible to chronic illness and disabilities ${ }^{4}$. Stunting mainly explains an overall long term nutritional condition and is the foremost child health outcome because of its relationship with child morbidity, mortality, and adult performance later in life.

According to the regional estimates of 2014, south Asian countries, especially India, Pakistan, and Bangladesh, are facing malnutrition problem ${ }^{5}$. In Pakistan, malnutrition rates are seen very high as compared to the developed world 6 . The stunting rate decreased from $67 \%$ in 1977 to $40-50 \%$ until the end of the 1990s. It is still very high when it is compared to global average rate. According to the National Nutrition Survey $(2011)^{7}$, the rate of infant stunting in Pakistan was $43.7 \%$. A higher stunting rate in rural areas $(46.3 \%)$ relative to urban areas $(36.9 \%)$ is an alarming situation. This huge difference in rural and urban stunting is mainly due to the difference of education and access to public health facilities. Pakistan Demographic and Health Survey (PDHS) also have stated the same conclusions about stunting.

Every year, millions of children are dying as a result of stunting in the world. In 2011,25\% worldwide children under age 5 have been found stunted. It is estimated that 165 millions kids, i.e. $80 \%$ of the world's stunted children, are living in 14 developing countries. Pakistan is also one of them. More than 9.6 million Children in Pakistan are experiencing chronic malnutrition (stunting) during the early age of their childhood and this number is the third highest over worldwide. The United Nations Children's Fund (UNICEF) passed a declaration to reduce stunting by $34 \%$ till 2017 with the cooperation of the Pakistan government ${ }^{8}$. Pakistan has shown an increasing commitment to the development of social sector, which have made some important achievements. Thus, UNICEF has launched a program named by "Stop Stunting" in Pakistan to obtain the desired outcome of 1.9 million fewer kids with stunted growth by 2017.

Comparative to short period measures of child health failure, stunting is the most meaningful measurement to detect the long term reasoning of child growth failure and it is much more helpful to get the Millennium Development Goals of one and four (poverty and child growth). In addition, short term indicators of wasting and overweight can easily be cured by improvements in nutrition, while stunting can be permeative, by influencing the important organs, i.e. brain and kidneys, which in turn impacts $I Q$, education, income level, various chronic diseases etc. ${ }^{9}$. Stunting is a logical indicator which gives a detailed summary of child health deficit ${ }^{10}$. Consequently, stunted children are more susceptible to infections and have poor cognitive growth, lower learning performance in their childhood ${ }^{1,12}$, decreased adult stature, reduced productivity and salary in adulthood ${ }^{13,14}$. Many empirical evidences support the view that these influences maybe passed on to the later generations ${ }^{15}$.
An overview of the earlier literature helps to identify the aims of the current study. The objectives of the current study is to prove that stunting is a reasonable indication for infant health outcome; and to examine the effect of mother schooling and related linkages on infant stunting. Following the earlier literature, a higher illiteracy rate of mothers in rural-urban Pakistan will evaluate the significance of mother education in determining stunting (long run infant health outcome) using Demographic and Health Survey, 2012-13 (DHS) dataset. It is anticipated that under the light of current study's findings, where decision makers will be able to propose logical strategy to upgrade the nutritional level of children age under five, it will also motivate the family to change its fatalistic and traditional thought of medical health care to accepting and utilizing the latest health services via improving female awareness and autonomy.

\section{MATERIALS AND METHODS}

The data on all explained and explanatory variables were taken from PDHS 2012-13. The data on all infants aged 0-59 months, whose height and weight were measured at the survey time, were selected for empirical analysis.

The dependent variable of this study is infant stunting (long run infant nutritional deficit). Height-for-age measures the linear growth of children. A child whose Z-score for height-for-age is more than two standard deviations (-2SD) below the median of the World Health Organization (WHO) reference population is considered stunted. Finally, the dependent variable is stunting (stunted $=1$ vs. normal $=0)^{16,17,18}$.

\section{$Z-$ Score $=\frac{\text { Measured Value }- \text { Average Value for the Reference population }}{\text { Standard Deviation of the Reference population }}$}

WHO Anthro software was utilized to build height-for-age z-scores to represent stunting.

\section{DESCRIPTION OF INDEPENDENT VARIABLES}

Mother formal schooling: This key confounding variable was classified as no schooling $=0$, primary schooling $=1$ and secondary/higher schooling $=2$.

Household wealth index: It presents her socioeconomic level. Principle component analysis was used to calculate the wealth index by DHS. In short, wealth index scores were classified as poor $=0$ and rich $=1$.

Protected water: It was used as proxy for household head environment condition. The supply of drinking water often verifies the quality of water consumed by children and other family members. In this study, drinking water was categorized into two sources such as protected $=0$ and not protected $=1$.

Gender of household head: It was a suitable proxy for mother empowerment (male $=0$ and female $=1$ ).

Mother visiting to a doctor for prenatal care: It was a proxy for health seeking mind-set. Knowledge of family planning/knowledge of tuberculosis disease (if she does not know about them $=0$ and otherwise $=1$ ) indicates her health care information. 
Mother body mass index (BMI) (BMI = weight $\mathrm{kg} /$ height $\mathrm{m}^{2}$ ): It was categorized as underweight $=0$ $\left(\mathrm{BMI}<18.5 \mathrm{~kg} / \mathrm{m}^{2}\right)$, normal=1 (BMI 18.5-24.9 kg/m²), overweight $=2\left(B M I 25.0-29.9 \mathrm{~kg} / \mathrm{m}^{2}\right)$, and obese $=3$ $\left(B M I \geq 30.0 \mathrm{~kg} / \mathrm{m}^{2}\right)$. It explained her nutrition status.

Breastfeeding: Not breastfed $=0$ and breastfed $=1$ illustrates child care attitude.

Living children in a household and mother age at first birth (continuous variables): The living children take into account of parents' time for childcare where they also measure birth space (reproductive behavior). These proxy explanatory variables were used for empirical analysis in the absence of their direct measures in database.

Child birth weight (continuous variable): It represents his biological condition.

Mother economic status (not working $=0$ and working $=1$ ), child gender (male $=0$ and female $=1$ ), and child age (continuous variable) measuring gender inequality ${ }^{19}$ are controlled demographic and socioeconomic factors.

\section{BIVARIATE AND BINARY LOGIT ANALYSES}

Both bivariate and binary logit analyses were used to determine the effect of mother formal schooling on rural-urban infant stunting after controlling for other factors deeply linked to her schooling. These types of analyses offered two conclusions about rural-urban child stunting; whether they are stunted or not. To conduct bivariate analysis, the chi-square statistics was used to find the connection between each of the explanatory variables and the children nutritional status for a long period (stunting). The chi-square bivariate analysis did not incorporate confounding impacts; thus, binary logit model was used to show the net effects of each confounder controlling other factors. Finally, as dependent variable was in the binary form, binary logistic regression model was employed based on a final sample size of 1,930 and 1,397 for urban and rural regions, respectively. A p $<0.05$ probability value highlights statistically significance of the predictors and all analyses were conducted with the help of SPSS.

\section{ETHICS APPROVAL AND CONSENT TO PARTICIPATE}

There was no need any ethical approval for this research because it is based on the Pakistan Demographic Health Survey 2012-13 secondary data collected by National Institute of Population Studies Islamabad, Pakistan. Therefore, any consent from participants was not needed.

\section{RESULTS}

The empirical and descriptive outcomes regarding the key objective of this paper are given in table 1. Empirical results of bivariate analysis showed a significant relationship between mother schooling, her health seeking attitude, socioeconomic level, empowerment, environment, child sex, weight and age, and rural-urban infant stunting. The proportion of infants suffering from chronic malnutrition was higher in rural location than in urban location. The data depicted an interesting picture of mothers' schooling: the population of illiterate mothers was higher in the urban region (52.7\%) than in rural location (32.3\%); and rural mothers showed more secondary/higher schooling (37.4\%) than urban mothers (12.3\%). Another important factor revealed that majority of the poor households (33.6\%) belonged to urban region, and rich class (93.6\%) lived in rural area. Surprisingly, $91.6 \%$ urban and $94.6 \%$ rural households were headed by males.

It implies that majority of the mothers were running homes in both regions. A total of $81.4 \%$ urban and 88.3\% rural households were deprived from safe drinking water. On average, mother age at $1^{\text {st }}$ birth (21 years old), living children (four), their weight $(10 \mathrm{~kg})$, and their age (30 months old) were coincided in both regions. Mother normal nutritional level was little satisfactory in both regions (60.0\% in urban area and $49.7 \%$ in rural region). About infants deprived from breastfeeding, $41.7 \%$ were from urban areas and $47.2 \%$ from rural areas (Table 1).

Tables 2 and 3 depict binary logistic results. Odds ratio $(\mathrm{OR})$ was taken into account of explaining significance level of explanatory variables. Comparing with illiterates, urban mothers having primary and secondary/higher $(O R=0.765 \& 0.616 ; p<0.05)(1$ - exponent of the log odds) were facing little less chances of stunting for their infants than rural mothers $(O R=0.776 \& 0.669$; $p<0.1 \& 0.05)$. Approximately, infants with the odds of 1.397 and 1.552 were more stunted $(O R=1.397 \&$ $1.552 ; p<0.10$ ) as households were headed by male in both urban and rural regions, respectively.

Relative to rich household, infants were 1.544 and 1.662 times $(\mathrm{OR}=1.544 \& 1.662 ; p<0.01 \& 0.05)$ more likelihood of stunting in both urban-rural locations, respectively, as they lived in a poor household. Mothers' attitude toward avoiding from advanced medical amenities resulted in more chances of infant stunting with the odds of 1.295 and $1.615(\mathrm{OR}=1.295 \& 1.615 ; p<0.01)$ in both urban-rural resident areas, respectively, against mothers struggling for better medical care. An insignificant relationship between health information and infant stunting was assessed. The heavier infants were estimated less stunted by $25 \%(\mathrm{OR}=0.756 ; \mathrm{p}<0.01)$ and $21 \%(\mathrm{OR}=$ $0.790 ; p<0.01)$ in urban and rural regions, respectively. Male infants in both urban $(O R=1.219 ; p<0.1)$ and rural areas $(O R=1.229 ; p<0.05)$ were more susceptible to stunting comparing with female kids. The likelihood of infant stunting was 1.057 and 1.045 times (OR $=1.057$ and 1.045; $\mathrm{p}<0.01$ ) higher, with an increasing trend of child age in both locations, but this effect was looking weaker. Only rural infants who were not breastfed were relatively found more stunted $(\mathrm{OR}=1.243 ; \mathrm{p}<0.1)$. The number of infants being a reproductive factor has not a significant impact on stunting. As urban mother age increased at the time of first birth, it leaded to only 3\% (OR $=0.973 ; p<0.05)$ less chances of her child stunting; however this impact got weaker. Mother nutritional rank and her economic working had insignificant association with infant stunting controlling for other variables. Only better urban environment condition (indicated by protected water) was causing 23\% (OR = 0.772; $p<0.05)$ less chronic malnutrition for infants. Preliminary empirical analysis confirmed no violation of the following assumptions (normality, heteroscedasticity, and multicollinearity). 
Table 1 - Descriptive and bivariate analysis

\begin{tabular}{|c|c|c|c|c|}
\hline Variables & $\begin{array}{l}\text { Urban infants } \\
N=1,930\end{array}$ & Chi-square (sig.) & $\begin{array}{l}\text { Rural infants } \\
N=1,397\end{array}$ & Chi-square (sig.) \\
\hline Stunted & $978(50.7 \%)$ & & $628(45.0 \%)$ & \\
\hline Not stunted & $952(49.3 \%)$ & & $769(55.0 \%)$ & \\
\hline Mother formal schooling & & $35.25(0.000)^{*}$ & & $39.62(0.00)^{*}$ \\
\hline No schooling & $1,018(52.7 \%)$ & & $451(32.3 \%)$ & \\
\hline Primary schooling & $675(35.0 \%)$ & & $423(30.3 \%)$ & \\
\hline Secondary/higher schooling & $237(12.3 \%)$ & & $523(37.4 \%)$ & \\
\hline Socioeconomic status & & $29.81(0.000)^{*}$ & & $22.27(0.00)^{*}$ \\
\hline Poor & $648(33.6 \%)$ & & $90(6.4 \%)$ & \\
\hline Rich & $1,282(66.4 \%)$ & & 1,307 (93.6\%) & \\
\hline Health knowledge & & $1.34(0.24)$ & & $1.98(0.27)$ \\
\hline Heard family planning & $365(18.9 \%)$ & & $455(32.6 \%)$ & \\
\hline Did not heard about family planning & $1,565(81.0 \%)$ & & $942(67.4 \%)$ & \\
\hline Gender of household head & & $3.32(0.05)^{\dagger}$ & & $2.56(0.099)^{\ddagger}$ \\
\hline Male & $1,768(91.6 \%)$ & & $1,322(94.6 \%)$ & \\
\hline Female & $162(8.4 \%)$ & & $75(5.4 \%)$ & \\
\hline Mother working & & $1.27(0.25)$ & & $0.682(0.4)$ \\
\hline Not working & $1,419(73.5 \%)$ & & $1,161(83.1 \%)$ & \\
\hline Working & $494(25.6 \%)$ & & $226(16.2 \%)$ & \\
\hline Mother BMI & & $4.043(0.25)$ & & $5.94(0.11)$ \\
\hline Underweight & $260(13.5 \%)$ & & $112(8.0 \%)$ & \\
\hline Normal & $1,158(60.0 \%)$ & & $694(49.7 \%)$ & \\
\hline Overweight & $380(19.7 \%)$ & & $395(28.3 \%)$ & \\
\hline Obese & $132(6.8 \%)$ & & 195 (14.0\%) & \\
\hline Breastfeeding & & $0.057(0.811)$ & & $1.005(0.31)$ \\
\hline No & $804(41.7 \%)$ & & $660(47.2 \%)$ & \\
\hline Yes & $1,126(58.3 \%)$ & & 737 (52.8\%) & \\
\hline Child sex & & $6.52(0.04)^{\dagger}$ & & $4.53(0.08)^{\ddagger}$ \\
\hline Male & 985 (51.0\%) & & 719 (51.5\%) & \\
\hline Female & 945 (49.0\%) & & $678(48.5 \%)$ & \\
\hline Safe drinking water & & $3.50(0.05)^{\dagger}$ & & $2.94(0.86)^{\ddagger}$ \\
\hline Protected water & $359(18.6 \%)$ & & $164(11.7 \%)$ & \\
\hline Not protected water & $1,571(81.4 \%)$ & & $1,233(88.3 \%)$ & \\
\hline Living infants & & $18.74(0.095)^{\ddagger}$ & & $32.01(0.004)^{*}$ \\
\hline Mother age at $1^{\text {st }}$ birth & & $57.44(0.0)^{*}$ & & $28.00(0.30)$ \\
\hline Child weight $(\mathrm{kg})$ & & $145.8(0.001)^{*}$ & & $199.9(0.05)^{\dagger}$ \\
\hline Child age (months) & & $95.28(0.002)^{*}$ & & $94.66(0.00)^{*}$ \\
\hline Health seeking attitude & & $17.7(0.000)^{*}$ & & $42.05(0.00)^{*}$ \\
\hline No & $1,262(65.4 \%)$ & & $584(41.8 \%)$ & \\
\hline Yes & $659(34.1 \%)$ & & $813(58.2 \%)$ & \\
\hline
\end{tabular}

${ }^{*} p<0.01 ;{ }^{\dagger} p<0.05 ;{ }^{\ddagger} p<0.10$. 
Table 2 - Empirical association between urban child stunting and its determinants

\begin{tabular}{|c|c|c|c|c|c|}
\hline Variables & B & Sig. & OR & \multicolumn{2}{|c|}{$95.0 \% \mathrm{Cl}(\mathrm{LB}-\mathrm{UB})$} \\
\hline Socioeconomic status ( 1 ) & 0.435 & $0.000 *$ & 1.544 & 1.234 & 1.933 \\
\hline Mother working (1) & 0.094 & 0.421 & 1.098 & 0.874 & 1.380 \\
\hline Breastfeeding (1) & -0.015 & 0.892 & 0.985 & 0.796 & 1.220 \\
\hline No schooling & & Ref. & & & \\
\hline Primary schooling & -0.268 & $0.01^{*}$ & 0.765 & 0.618 & 0.948 \\
\hline Secondary/higher schooling & -0.485 & $0.00^{*}$ & 0.616 & 0.440 & 0.862 \\
\hline Child sex (1) & 0.206 & $0.036^{\ddagger}$ & 1.229 & 1.013 & 1.490 \\
\hline Child weight $(\mathrm{kg})$ & -0.280 & $0.00^{*}$ & 0.756 & 0.719 & 0.795 \\
\hline Age & 0.056 & $0.00^{*}$ & 1.057 & 1.047 & 1.068 \\
\hline Gender of household head (1) & 0.334 & $0.062^{\ddagger}$ & 1.397 & 0.983 & 1.986 \\
\hline Protected water (1) & -0.259 & $0.048^{+}$ & 0.772 & 0.597 & 0.998 \\
\hline Mother age at $1^{\text {st }}$ birth & -0.027 & $0.048^{\dagger}$ & 0.973 & 0.948 & 1.000 \\
\hline Health seeking attitude (1) & 0.258 & $0.01^{*}$ & 1.295 & 1.044 & 1.605 \\
\hline Mother BMI (underweight) & & Ref. & & & \\
\hline Normal & -0.380 & 0.115 & 0.684 & 0.427 & 1.097 \\
\hline Overweight & -0.243 & 0.235 & 0.784 & 0.525 & 1.172 \\
\hline Obese & 0.096 & 0.664 & 1.101 & 0.713 & 1.699 \\
\hline Living infants & -0.031 & 0.197 & 0.969 & 0.925 & 1.016 \\
\hline Health knowledge (1) & -0.088 & 0.500 & 0.916 & 0.710 & 1.182 \\
\hline Constant & 1.65 & 0.001 & 5.234 & & \\
\hline
\end{tabular}

B: Coefficients of the corresponding independent factors; Sig.: Level of significance at which regressor is affecting dependent factor; OR: Odds ratio; 95.0\% Cl: 95\% confidence interval; LB-UB: Upper bound and lower bound; ${ }^{*} p<0.01 ;{ }^{\dagger} p<0.05 ;{ }^{\ddagger} p<0.10$.

Table 3 - Empirical association between rural child stunting and its determinants

\begin{tabular}{|c|c|c|c|c|c|}
\hline Variables & B & Sig. & OR & \multicolumn{2}{|c|}{$95.0 \% \mathrm{Cl}$ (LB-UB) } \\
\hline Breastfeeding (1) & 0.217 & $0.087^{\ddagger}$ & 1.243 & 0.969 & 1.594 \\
\hline Child sex (1) & 0.198 & $0.085^{\ddagger}$ & 1.219 & 0.973 & 1.528 \\
\hline Child weight $(\mathrm{kg})$ & -0.236 & $0.00^{*}$ & 0.790 & 0.744 & 0.838 \\
\hline Living infants & 0.033 & 0.305 & 1.034 & 0.970 & 1.101 \\
\hline Socioeconomic status (1) & 0.508 & $0.05^{+}$ & 1.662 & 0.992 & 2.784 \\
\hline Health seeking attitude (1) & 0.479 & $0.00^{*}$ & 1.615 & 1.261 & 2.068 \\
\hline Mother age at $1^{\text {st }}$ birth & 0.014 & 0.360 & 1.015 & 0.984 & 1.046 \\
\hline Mother working (1) & -0.023 & 0.886 & 0.978 & 0.719 & 1.330 \\
\hline Protected water (1) & 0.109 & 0.545 & 1.115 & 0.783 & 1.588 \\
\hline Mother BMI (underweight) & & Ref. & & & \\
\hline Normal & -0.075 & 0.730 & 0.928 & 0.606 & 1.420 \\
\hline Overweight & -0.153 & 0.511 & 0.858 & 0.544 & 1.354 \\
\hline Obese & -0.165 & 0.524 & 0.848 & 0.511 & 1.408 \\
\hline No schooling & & Ref. & & & \\
\hline Primary schooling & -0.254 & $0.098^{\ddagger}$ & 0.776 & 0.574 & 1.048 \\
\hline Secondary/higher schooling & -0.401 & $0.01^{*}$ & 0.669 & 0.486 & 0.921 \\
\hline Gender of household head (1) & 0.439 & $0.096^{\ddagger}$ & 1.552 & 0.925 & 2.604 \\
\hline Age & 0.044 & $0.00^{*}$ & 1.045 & 1.032 & 1.057 \\
\hline Health knowledge (1) & -0.151 & 0.235 & 0.860 & 0.671 & 1.103 \\
\hline Constant & 0.227 & 0.673 & 1.254 & & \\
\hline
\end{tabular}

B: Coefficients of the corresponding independent factors; Sig.: Level of significance at which regressor is affecting dependent factor; OR: Odds ratio; 95.0\% Cl: 95\% confidence interval; LB-UB: Upper bound and lower bound; ${ }^{*} p<0.01 ;{ }^{\dagger} p<0.05 ;{ }^{\ddagger} p<0.10$. 
Table 4 - Empirical association between urban child stunting and its determinants

\begin{tabular}{|c|c|c|c|c|c|}
\hline & \multirow{2}{*}{ Subject factor } & \multirow{2}{*}{ Region } & \multicolumn{2}{|c|}{ Predicted values } & \multirow{2}{*}{$\%$ age correct } \\
\hline & & & Normal children & Stunted children & \\
\hline \multirow{4}{*}{ Observed values } & \multirow{2}{*}{ Normal children } & Urban & 584 & 181 & 76.3 \\
\hline & & Rural & 604 & 340 & 64.0 \\
\hline & \multirow{2}{*}{ Stunted children } & Urban & 306 & 316 & 50.8 \\
\hline & & Rural & 301 & 659 & 68.6 \\
\hline \multirow{2}{*}{\multicolumn{2}{|c|}{ Overall percentage }} & Urban & & & 64.9 \\
\hline & & Rural & & & 66.3 \\
\hline
\end{tabular}

The cut value is 0.50 .

Table 4 presents both sensitivity and specificity diagnostic analysis. The sensitivity analysis concluded that $76.3 \%$ and $64.0 \%$ babies were correctly assessed without stunting issue by their mothers, while the specificity analysis indicated that about $50.8 \%$ and $68.6 \%$ children was accurately a victim of stunting subject in the urban and rural regions, respectively. The overall success rate of prediction was $64.9 \%$ and $66.3 \%$ for both regions, respectively, that was above the threshold level. Thus, both diagnostic tests leaded to the significance of odd ratios in the logistic regression. Furthermore, Hosmer Lemeshow test showed that insignificant value of chi-square points out that the data best fit the model.

\section{DISCUSSION}

Being a national, large, and consistent data, the DHS database facilitates to explore the pattern of long term child health outcome in Pakistan. In these outcomes, primary and secondary/higher schooling of mothers was significantly recorded as more protective measure to escape under-five infants from stunting relative to mothers without education in both regions (urban and rural) of Pakistan. Mother's education impact on long run health outcome was higher in urban location than in rural area. Monteiro et al. ${ }^{20}$ and Deshmukh et al. ${ }^{21}$ also commented that the higher female education worked as a key factor contributing to reduce stunting in case of Brazil. The finding of the present study is also aligned with others ${ }^{10,22,23}$. Maternal formal education, as a proxy for socioeconomic status, was noticeably attached to less stunting in both urban and rural regions. A realistic expression for this relationship is that maternal schooling may directly affect child growth by increasing female knowledge and sovereignty in a family and community,24. As result, appropriate and meaningful health-seeking thoughts, hygiene, and better feeding practices are conveyed to mothers ${ }^{25}$. Some studies stated a negative link between mother education and infant mortality ${ }^{26}$. However, some studies are seen failed to explain an association between mother education and child health ${ }^{27}$. These findings imply that an improvement of child health status in the long run is considerably possible by the female formal schooling in both locations.

Mother with poor socio-economic rank was significantly linked to more chronic malnutrition for her kids in both regions because of having enough resources to maintain their nutrition and to save them from illness and deficiency of nutrients. This trend was higher in rural area than in urban location. This important conclusion is also supported by Boyle et al..$^{28}$ and Nkurunziza et al. ${ }^{29}$. Lower stunting in urban areas is a result of favorable economic conditions which leads to the most caring practices for infants and their mothers ${ }^{30}$. Ukwuani and Suchindran ${ }^{31}$ also confirms this findings, that infants linked to wealthy families have less chances of stunting as compared to children linked to poor families in Nigeria. These outcomes are completely contradicted to Fakir and $\mathrm{Khan}^{32}$ who proved that infant health is not impacted by household assets. A variety of research literature reveals that children having socioeconomic status are more stunted than those infants belong to rich backgrounds ${ }^{33,34}$.

Empirical outcomes in table 2 and 3 also declared rural-urban mother empowerment (shown by female household head) as a significant and effective explanatory variable which gives a guarantee better nutritional outcome in future. Hong and White-Means ${ }^{35}$ contradict to this result, but it is favored by Das Gupta ${ }^{36}$ who empirically estimated that mothers with strong influence and will in a family affairs (empowered mothers) have healthier infants. Simon et al. ${ }^{37}$ also favors the preceding outcome that female empowerment in household matters help to maximally utilize the scarce resources to get the optimal level of nutrition for their kids. While working females are understood economically more empowered, their relationship with infant stunting is inconsistent in our results. Another supporting argument is that urban women are generally observed with a higher decision-making influence relative to their counterparts ${ }^{30}$.

Higher child weight, in both locations, was significantly causing least chances of stunting as shown above. Favoring this study, Rahman et al. ${ }^{18}$ also reported the higher malnutrition risk among low birth weight infants. Child weight is also linked to the mother nutritional level explicitly during pregnancy ${ }^{38}$. Hence, healthy mothers have well healthy infants. However, these empirical estimates about mother nutrition reveals were highly insignificant. Only rural mothers feeding their infants were facing significantly less stunting risk for their infants because breastfeeding gives hygienic and better nutritional outcome, affects childhood life span, and prevents them from poor growth. Breastfeeding also saves infants from the threat of short term diseases and provides balance nutrients in foods. This conclusion is aligned with Mbwana et al. ${ }^{39}$. 
Mothers following health care attitude (indicated by prenatal care visit of mothers) in both regions (urban and rural) had not stunted infants because of availing health facilities timely. This trend was also stronger in rural region than urban area. A positive, but weaker impact of child age on stunting was estimated in both regions at a higher significant level. This result is also matched with Sarmiento et al. ${ }^{40}$. However, a positive, but insignificant association between health information and infant health was estimated.

Within reproductive variables, living children in ruralurban areas showed inconsistent outcome. This result is contradicted to Kavosi et al. ${ }^{41}$ who highlighted a greater risk of malnutrition in large families. Urban mothers had more stunting risk due to having less experience about health care. Ukwuani and Suchindran ${ }^{31}$ oppose this outcome.

The protected water, a proxy for household environment situation, was noticeably and negatively affecting infant stunting in urban region, because safe drinking water saves infant long term malnutrition. Anwar et al. ${ }^{42}$ favor this outcome via confirming a significant and negative link between toilet and secured drinking water facilities and stunting. Smith et al. ${ }^{30}$ estimated a weak association of piped water with infant nutritional status, but found out a strong and positive association in urban location.

To reduce stunting risk among infant age fewer than 5 years is the foremost target of the government of Pakistan and various worldwide agencies. Thus, it is important to identify the predictors that can directly or indirectly impact stunting so that the stakeholders can propose evidence-based policy for the betterment of long term child health. Identification of these factors has been a major challenge for the researchers of public health. Recent global studies have identified the following factors which can cause the child survival: maternal illiteracy, her nutritional status, breastfeeding, family income level, environmental conditions, many other demographic, social, and economic factors ${ }^{43,44}$. Many studies conducted on Pakistan, India, and Bangladesh called poor mothers' education, lower socio-economic position, low birth weight, and poor access to health center as the main risk factors $2,3,28,45$. In short, high illiteracy, poverty and food insecurity are the key reasons of increasing trends of acute and chronic malnutrition in Pakistan commission report $(2011)^{7}$.

Firstly, Caldwell ${ }^{46}$ concluded mothers' education is a key factor influencing the health of their children. He also estimated that the children of literate mothers enjoyed a good health relative to less educated or uneducated mothers. Education makes the mothers more active and helps them to take the right and quick decisions about their children's health problem ${ }^{47}$, birth space, and family size $^{22}$. National Nutrition Survey $(2011)^{7}$ concluded that mother education was closely related to infant stunting and found that the percentage of malnutrition was lower among the children of more educated and literate. According to latest PDHS's report, stunting ranges from $21 \%$ among children whose mothers have achieved higher education to $55 \%$ among those whose mothers have no education. A similar inverse relationship was observed between household wealth and stunting. Children in the poorest households were three times more likely to be stunted (62\%) than children in the wealthiest households $(23 \%)^{7}$. Some comparative studies showed a negative association between mother education and child survival ${ }^{48}$. Conversely, several past studies failed to estimate a strong causal link between mothers' formal education and child survival ${ }^{27}$. It has become a need to recognize the linkage through which maternal education links to infant health in both urban and rural locations.

Various studies dealing with the impact effect of mother formal schooling on child survival has presented many pathways. It is stated that parents schooling promoted infant health through their literacy and numeracy skills, health knowledge, and income. They also presented potential pathways associating mother education to child survival, i.e. health-related information, numeracy expertise, and exposure to advanced society which enabled mothers more responsive to latest medications ${ }^{25}$. Communities containing educated females were enriched with better clinical, piped water, and sanitation amenities, and they provided an environment of exchange of health care information ${ }^{27}$. There are only few empirical works examined the relative contribution of these pathways, particularly in one study of Frost et al. ${ }^{47}$, but this work also considers these pathways in context of disparities that are evident among mothers' economic and nutritional position, health knowledge, health seeking thought, reproductive behavior, and empowerment in both rural-urban locations of Pakistan. Furthermore, maternal nutritional level may also be included as a pathway linking maternal schooling to child survival. Thus, this unique study estimates the impact of mother schooling on chronic malnutrition incorporating all possible pathways mentioned earlier on the ground of rural urban inequalities.

\section{CONCLUSION}

This study findings imply that female education, along with various other pathways (her socioeconomic, empowerment, and heal seeking thought), has reduced chronic malnutrition and has been a guarantee of better living standard, still targeted interventions are important aiming at mothers having no education by specifying a big share of federal and regional budget on female education. Furthermore, targeted outcomes can be achieved through functionalizing this budget via both (federal and provincial) educational ministries. Particularly, public and private institutions should enhance the enrollment for secondary/ postsecondary classes because it shows strong link with long-term child health in both regions. Individually, mothers (especially the young ones) should learn health care knowledge from different channels. For this purpose, UNICEF is also facilitating Pakistan to enhance children nutrition level. Breastfeeding rate should be improved by mothers and they should be away from higher usage of infant formulas as suggested by UNICEF. For enhancing nutritional condition of children age fewer than 5 years in Pakistan, some interventions are urgent aiming at reducing incidence of low birth weight besides improving women's formal schooling. 
The validity of this study is that it is supported by PDHS 2012-13 dataset on child birth weight and other variables which are collected by a trustworthy source of National Institute of Population Studies Islamabad, Pakistan. However, there are some limitations in the present study. Firstly, only a selected sample of newborn babies, whose mothers could record their birth weight on health card during the survey, was considered. Secondly, many important variables, like maternal nutrition level, life style, and their diet, could not be controlled in the study due to lack of these variables in the survey data. Thirdly, several proxy variables, for instance mother empowerment, economic status, reproductive attitude, environment, knowledge, and health seeking mind-set were incorporated in this study because of not finding their direct measures in the dataset.

\section{ACKNOWLEDGMENTS}

The authors would like to thank Dr. Shaoan Huang's supervision in this research work.

\section{FINANCIAL SUPPORT}

The authors declared that this study received no financial support.

\section{AVAILABILITY OF DATA AND MATERIALS}

The datasets used and analyzed in the current study is available from the corresponding author on reasonable request.

\section{PRIOR PRESENTATION}

Data from this study was presented and published by international agency, USAID, with the title of "Pakistan Demographic and Health Survey 2012-13"

\section{CONFLICTS OF INTERESTS}

The authors declared that they have no conflict of interest.

\section{AUTHORS CONTRIBUTION}

All authors contributed to study idealization, analysis and interpretation of data and manuscript writing, approving the published final. They declare themselves responsible for content of the article, ensuring its accuracy and integrity.

\section{REFERENCES}

1 Jesmin A, Yamamoto SS, Malik AA, Haque MA. Prevalence and determinants of chronic malnutrition among preschool children: a cross-sectional study in Dhaka city, Bangladesh. J Health Popul Nutr. 2011 Oct;29(5):494-9.

2 Friesen VM, Aaron GJ, Myatt M, Neufeld LM. Assessing coverage of population-based and targeted fortification programs with the use of the fortification assessment coverage toolkit (FACT): background, toolkit development, and supplement overview. J Nutr. 2017 May;147(5):981S-3.

3 Abuya BA, Ciera J, Kimani-Murage E. Effect of mother's education on child's nutritional status in the slums of Nairobi. BMC Pediatr. 2012 Jun;12:80.

4 Khanam R, Nghiem HS, Rahman MM. The impact of childhood malnutrition on schooling: evidence from Bangladesh. J Biosoc Sci. 2011 Jul;43(4):437-51.

5 Das S, Hossain MZ, Islam MA. Predictors of child chronic malnutrition in Bangladesh. Proc Pakistan Acad Sci. 2008;45(3):137-55.

6 Bhutta ZA, Ahmed T, Black RE, Cousens S, Dewey K, Giugliani E, et al. What works? Interventions for maternal and child undernutrition and survival. Lancet. 2008 Feb;371 (9610):417-40.

7 Planning Commission. National Nutrition Survey 2011 . Islamabad, Pakistan; 2011.

8 United Nations Children's Fund. Improving child nutrition: the achievable imperative for global progress. New York: UNICEF; 2013.
9 Schmidt CW. Beyond malnutrition: the role of sanitation in stunted growth. Environ Health Perspect. 2014 Nov;122(1 1):A298-303.

10 Slemming W, Kagura J, Saloojee H, Richter LM. Early life risk exposure and stunting in urban South African 2-year old children. J Dev Orig Health Dis. 2017 Jun;8(3):301- 10.

11 Caulfield LE, Onis M, Blössner M, Black RE. Undernutrition as an underlying cause of child deaths associated with diarrhea, pneumonia, malaria, and measles. Am J Clin Nutr. 2004 Jul;80(1):193-8.

12 Walker SP, Wachs TD, Gardner JM, Lozoff B, Wasserman GA, Pollitt E, et al. Child development: risk factors for adverse outcomes in developing countries. Lancet. 2007 Jan;369(9556): 145-57.

13 Liu Y, Albertsson-Wikland K, Karlberg J. Long-term consequences of early linear growth retardation (stunting) in Swedish children. Pediatr Res. 2000 Apr;47(4 Pt 1):475-80.

14 Victora CG, Adair L, Fall C, Hallal PC, Martorell R, Richter $L$, et al. Maternal and child undernutrition: consequences for adult health and human capital. Lancet. 2008 Jan;371 (9609):340-57.

15 Prendergast AJ, Humphrey JH. The stunting syndrome in developing countries. Paediatr Int Child Health. 2014 Nov;34(4):250-65.

16 Onis M, Branca F. Childhood stunting: a global perspective. Matern Child Nutr. 2016 May; 12 Suppl $1: 12-26$. 
17 Khatun S, Rahman M. Socio-economic determinants of low birth weight in Bangladesh: a multivariate approach. Bangladesh Med Res Counc Bull. 2008 Dec;34(3):81-6.

18 Rahman MS, Howlader T, Masud MS, Rahman ML. Association of low-birth weight with malnutrition in children under five years in Bangladesh: do mother's education, socio-economic status, and birth interval matter? PLoS One. 2016;11(6):1-16.

19 Borooah VK. The height-for-age of Indian children. Econ Hum Biol. 2005 Mar;3(1):45-65

20 Monteiro CA, Benicio MH, Conde WL, Konno $S$, Lovadino $A L$, Barros $A J$, et al. Narrowing socioeconomic inequality in child stunting: the Brazilian experience, 1974-2007. Bull World Health Organ. 2010 Apr;88(4):305-11.

21 Deshmukh PR, Sinha N, Dongre AR. Social determinants of stunting in rural area of Wardha, Central India. Med J Armed Forces India. 2013 Jul;69(3):213-7.

22 Abuya BA, Onsomu EO, Kimani JK, Moore D. Influence of maternal education on child immunization and stunting in Kenya. Matern Child Health J. 2011 Nov; 15(8):1389-99.

23 Rachmi CN, Agho KE, Li M, Baur LA. Stunting, underweight and overweight in children aged 2.0-4.9 years in Indonesia: prevalence trends and associated risk factors. PLoS One. 2016 May; 11 (5):e0154756.

24 Monden CWS, Smits J. Maternal education is associated with reduced female disadvantages in under-five mortality in sub-Saharan Africa and southern Asia. Int J Epidemiol. 2013 Feb;42(1):21 1-8.

25 Black RE, Victora CG, Walker SP, Bhutta ZA, Christian $P$, Onis $M$, et al. Maternal and child undernutrition and overweight in low-income and middle-income countries. Lancet. 2013 Aug;382(9890):427-51.

26 Tiwari R, Ausman LM, Agho KE. Determinants of stunting and severe stunting among under-fives: evidence from the 2011 Nepal Demographic and Health Survey. BMC Pediatr. 2014 Sep; 14:239.

27 Desai S, Alva S. Maternal education and child health: is there a strong causal relationship? Demography. 1998 Feb;35(1):71-81.

28 Boyle MH, Racine Y, Georgiades K, Snelling D, Hong $\mathrm{S}$, Omariba W, et al. The influence of economic development level, household wealth and maternal education on child health in the developing world. Soc Sci Med. 2006 Oct;63(8):2242-54.

29 Nkurunziza S, Meessen B, Van Geertruyden JP, Korachais $C$. Determinants of stunting and severe stunting among Burundian children aged 6-23 months: evidence from a national cross-sectional household survey, 2014. BMC Pediatr. 2017 Jul;17(1):176.
30 Smith LC, Ruel MT, Ndiaye A. Why is child malnutrition lower in urban than in rural areas? Evidence from 36 developing countries. World Dev. 2005 Aug;33(8): 1285-305.

31 Ukwuani FA, Suchindran CM. Implications of women's work for child nutritional status in sub-Saharan Africa: a case study of Nigeria. Soc Sci Med. 2003 May;56(10):2109-21.

32 Fakir AMS, Khan MWR. Determinants of malnutrition among urban slum children in Bangladesh. Health Econ Rev. 2015 Jul;5:22.

33 Woldemariam G, Timotiows G. Determinants of nutritional status of women and children in Ethiopia. Ethiopia: Ethiopian Health and Nutrition Research Institute; 2002.

34 Kandala NB, Madungu TP, Emina JBO, Nzita KPD, Cappuccio FP. Malnutrition among children under the age of five in the Democratic Republic of Congo (DRC): does geographic location matter? BMC Public Health. $2011 ; 11(1): 261$.

35 Hong GS, White-Means SI. Do working mothers have healthy children? J Fam Econ Issues. 1993 Jun; 14(2): 163-86.

36 Das Gupta M. Death clustering, mothers' education and the determinants of child mortality in rural Punjab, India. Popul Stud. 1990;44(3):489-505.

37 Simon D, Adams AM, Madhavan S. Women's social power, child nutrition and poverty in Mali. J Biosoc Sci. 2002 Apr;34(2):193-213.

38 Stein AD, Wang M, Martorell R, Norris SA, Adair LS, Bas I, et al. Growth patterns in early childhood and final attained stature: data from five birth cohorts from low-and middle-income countries. Am J Hum Biol. 2010 May-Jun;22(3):353-9.

39 Mbwana HA, Kinabo J, Lambert C, Biesalski HK. Factors influencing stunting among children in rural Tanzania: an agro-climatic zone perspective. Food Secur. $2017 \mathrm{Dec} ; 9(6): 1157-71$.

40 Sarmiento OL, Parra DC, González SA, González-Casanova I, Forero AY, Garcia J. The dual burden of malnutrition in Colombia. Am J Clin Nutr. 2014 Dec;100(6): 1628S-35.

41 Kavosi E, Hassanzadeh Rostami Z, Kavosi Z, Nasihatkon A, Moghadami M, Heidari M. Prevalence and determinants of under-nutrition among children under six: a cross-sectional survey in Fars province, Iran. Int J Health Policy Manag. 2014 Jul;3(2):71-6.

42 Anwar S, Nasreen S, Batool Z, Husain Z. Maternal education and child nutritional status in Bangladesh: evidence from demographic and health survey data. PakJ Life Soc Sci. 2013;11(1):77-84.

43 Kraemer K. Making stunting a development indicator. Sight Life. 2016;30(1):10-2. 
44 Okwaraji YB, Edmond KM. Proximity to health services and child survival in low-and middle-income countries: a systematic review and meta-analysis. BMJ Open. 2012 Jul;2(4).

45 Rahman MS, Howlader T, Masud MS, Rahman ML. Association of low-birth weight with malnutrition in children under five years in Bangladesh: do mother's education, socio-economic status, and birth interval matter? PLoS One. 2016 Jun; 11(6):e0157814.
46 Caldwell JC. Education as a factor in mortality decline an examination of Nigerian data. Popul Stud. 1979 Nov;33(3):395-413.

47 Frost MB, Forste R, Haas DW. Maternal education and child nutritional status in Bolivia: finding the links. Soc Sci Med. 2005 Jan;60(2):395-407.

48 Bicego GT, Boerma JT. Maternal education and child survival: a comparative study of survey data from 17 countries. Soc Sci Med. 1993 May;36(9):1207-27. 